\author{
S.T. Mussina ${ }^{1}{ }^{*}$, Zh.S. Khusainova ${ }^{2}$, Y.A. Vechkinzova ${ }^{3}$ \\ ${ }^{1,2}$ Karagandy University of the name of academician E.A. Buketov, Kazakhstan \\ ${ }^{3}$ Institute of management problems named after V.A.Trapeznikov of the Russian Academy of Sciences, Russia \\ ${ }^{1}$ mussina.74@mai.ru, ${ }^{2}$ zhibekh11@mail.ru, ${ }^{3}$ kvin07@list.ru, \\ ${ }^{1}$ https://orcid.org/0000-0003-1647-3921, ${ }^{2}$ http://orcid.org/0000-0002-2617-838X, \\ ${ }^{3}$ https://orcid.org/0000-0003-2543-625X \\ ${ }^{2}$ Scopus Author ID: 57195557031, ${ }^{3}$ Scopus Author ID: 57211264312
}

\title{
Migration processes in Kazakhstan: Trends, specifics, factors
}

\section{Abstract}

Object: to identify the main trends in external and internal migration in Kazakhstan, to study the characteristics of its different flows, and to describe the economic and demographic factors affecting migration processes. Migration processes in the Republic of Kazakhstan

Methods: methods of system, dynamic and structural analysis, and methods of studying cause-andeffect relationships.

Results: We have identified trends in external and internal migration in Kazakhstan in the last decade; we have studied the characteristic features of migration flows in Kazakhstan and the factors affecting the migration activity of the population; we have addressed the issue of unregulated migration in Kazakhstan and described the risks associated with it, as well as the possibility of migration policies in addressing this issue.

Conclusions: In recent years, the negative balance of external migration has been growing; there is a net outflow from Kazakhstan. The intensity of ethnic repatriation of Kazakhs, which previously would block the flow of emigration, is now decreasing. Measures are needed to halt the outflow of migrants from Kazakhstan and to encourage immigration into Kazakhstan. In recent years, the state has been actively pursuing an internal migration policy: mechanism for registering migrants within the country has been strengthened, and a quota has been established for resettlement to the northern and north-eastern regions of Kazakhstan.

Keywords: migration, external migration, internal migration, unregulated migration, migration intensity, economic factors of migration, migration policy.

\section{Introduction}

The world's population mobility has been growing rapidly in recent years, and there is whole multitude of reasons for this. These include globalization, which has led to the fact that labor markets from local and domestic closed markets have become increasingly integrated into international labor markets with intensive external labor and educational migration. The expansion of the information space has also largely influenced the intensification of migration; with the development of communication tools and the spread of the global Internet, people can assess their own conditions and where they would like to go. Details on the availability of more attractive conditions in other countries motivate potential migrants to decide sooner about moving to other countries, or to other regions of the same country. In the era of digital technologies and global connectivity, young people are increasingly participating in global educational migration flows. And if earlier educational migration flows were more linked to urbanization processes when rural youth would seek to study in cities and would eventually stay there (return migration would turn into nonreturn one), in the modern world these flows are more complicated. Advanced young people from developing countries seek education in prestigious universities around the world, while in developed countries there is a "battle for brains" when countries with depopulation processes and an aging population seek to attract talented young people and highly qualified personnel from less developed countries. In turn, the countries that are donors of educational and labor migration, are starting to feel the impact of "brain drain" on prospects of demographic development and damage to the future economic development of the country (promising personnel are getting washed out, and the aging trends of the local population accelerate over time). In recent years, migration flows of forced migration have increased due to wars, local conflicts between population groups, and natural disasters forcing people to leave their cities and villages and become refugees.

\footnotetext{
*Corresponding author.

E-mail.E-mail: mussina.74@mai.ru
} 
Kazakhstan is hardly a stranger to these trends as processes of both external and internal migration are actively developing in our country as well. In this paper, we shall review the dynamics of migration processes in Kazakhstan, try to identify the specifics of external and internal migration flows in our country, and describe the main factors affecting the dynamics of migration both in the country and abroad. Our contribution to the study of migration issues will consist in our own interpretation of the migration processes that have taken place in Kazakhstan in recent years, and in the analysis of factors stimulating or halting the growth of mobility of Kazakhstan citizens.

We assume that processes of external migration in Kazakhstan are influenced by the following: socioeconomic conditions, internal motivation of people, ethno-cultural motives (motives of attachment to the historic homeland, a desire to preserve national identity, language environment). We also proceed from the hypothesis that in Kazakhstan, external migration processes occur as part of the ethnic repatriation of European ethnic groups from Kazakhstan and ethnic Kazakhs into Kazakhstan. In addition to nonreturn external migration, the flows of which are reflected in demographic statistics, the flows of return migration (especially educational and labor migration) are also of significant importance in the migration processes in our country. We need to take these flows into account, since they are associated with great risks, a "brain drain" and loss of the demographic dividend due to the transformation of return migration into nonreturn one.

\section{Literature Review}

The HSE University's own online magazine Demoscope Weekly publishes materials on migration processes in the post-Soviet space, including those in Kazakhstan. This magazine posts topics on all demographic processes (birth, mortality, migration, marriage, and divorce rates). In particular, there are articles by Kazakh scientists Y.Y.Sadovskaya (Sadovskaya, 2009) and A.N.Alekseyenko (Alekseyenko, 2008) who raise issues of immigration into Kazakhstan (Chinese migration, ethnic repatriation, internal migration, etc.).

Also, a number of publications and analytical materials on migration processes in the Central Asian region, including those in Kazakhstan, can be found on the home page of the Kazakhstan office of the International Organization for Migration (hereinafter referred to as IOM) at kazakhstan.iom.int. IOM experts consider issues of protection of migrants in vulnerable situations, youth migration, return migration, unregulated migration, and other topical issues in this area.

Sources of statistical data on migration in Kazakhstan include compilations, bulletins, and dynamic tables in the section "Demographic statistics" of the Committee on Statistics of the MNE RK at stat.gov.kz. Indicators of migration movement of the population are presented in the context of external and internal flows by countries, age categories, ethnic groups, and regions within Kazakhstan. Source of data on labor migration within the EAEU is the Eurasian Economic Commission's home page at eurasiancommission.org. Data on international educational migration (including Kazakhstan) is available on the UNESCO Institute for Statistics' home page at data.uis.unesco.org.

A whole multitude of scientists and analysts address the migration factors, but in general all of them can be grouped as follows:

1) Push and pull theory by Everett S. Lee (Lee, 1966), in which he highlights the push and pull factors of migration flows. He also emphasizes that the desire of a potential migrant to leave is influenced by the following unidirectional and multidirectional forces and motives (both strengthening or weakening): border crossings, the cost of housing in a new location, and others that may be surmountable obstacles for some migrants, and insurmountable for the other, negatively affecting their decision to leave.

2) Theories that consider the distance between the points of departure and arrival of migrants to be the main factor of migration. Its foundations were laid in 1885 by Ernst Georg Ravenstein (Ravenstein, 1885). He believed that migration flows mainly spread over short distances. Moreover, he stressed that the main motives for migration are economic. In support of this theory, George Kingsley Zipf (Zipf,1949) has introduced the principle of least effort, or least resistance used by migrants when deciding where to go. He proposed a gravity model of migration. The intensity of the migration flow between two objects in the gravitational model will depend on the distance between them and some measure of their significance (magnitude). Population figures are usually taken as a measure of significance.

3) Theories that study the economic factors of migration. W.A. Lewis (Lewis, 1954) has made a significant contribution to development of this direction (in his dual-sector model of the economy he pays attention to the factors of moving from rural to urban); J. Harris and M. Todaro (Harris, Todaro, 1970) have studied effects of expected wages in urban and rural on migration from rural to urban based on the likelihood of getting a job in the city. 
4) Theories that study migration as part of the globalization processes, Stephen Castles and Mark J. Miller (Castles, Miller, 1993) have considered migration flows between developed and developing countries in the light of issues of ethnic, labor migration and migration policies of countries, Saskia Sassen (Sassen, 1988) has shown the impact of foreign investment on external migration and the impact of international organizations on migration flows.

\section{Methods}

The object of the study is migration processes within Kazakhstan and with the participation of Kazakhstan - external emigration from our country and immigration to our country.

The research objectives are:

- study of trends in the development of external migration processes - flows from the country to the country within the framework of migration for permanent residence, ethnic, educational and labor migration, as well as trends in migration movement within the country (between regions of the country, from village to city);

- consideration of factors affecting the intensity of migration from / to the country and within the country, directly or indirectly determining the migration mood of the population in the country both in the countries of origin of migrants arriving in Kazakhstan and in the countries of departure of emigrants from Kazakhstan;

- identification of the role of migration policy in Kazakhstan in regulating migration processes in the country and development of proposals to strengthen its measures and increase the effectiveness of the impact tools used.

The sources of data about the research object are:

- data of the Committee on statistics of MNE of RK, from October 2020 the National statistics Bureau of the Agency for strategic planning and reforms of the Republic of Kazakhstan;

- data of the National Bank of the Republic of Kazakhstan on money transfers from / to the country;

- data of the Ministry of labor and social protection on labor migration to Kazakhstan;

- UNESCO database on educational migration between countries of the world;

- analytical data on the website of the International organization for migration (IOM);

- analytical materials on the website of the Eurasian economic Commission;

- monographs and articles by domestic and foreign authors devoted both to the analysis of migration flows in Kazakhstan and with the participation of Kazakhstan, and to the assessment of various factors affecting the migration activity of the population in Kazakhstan and countries that are donors or recipients of migration to and from our country.

When processing statistical and departmental data describing the quantitative parameters of migration flows in Kazakhstan, the methods of dynamic (time series analysis) and structural (assessment of the contribution of constituent elements) analysis were used. This allows us to study trends in the development of migration processes in our country and assess the impact of multidirectional migration flows on the overall demographic situation in the country and in its individual regions.

The identification of factors affecting the intensity of internal and external migration in Kazakhstan was based on the study of cause-and-effect relationships between various parameters of socio-economic development in the country and in its regions (income and standard of living, labor market indicators, living conditions, etc.) and the dynamics of migration movement in the country.

The analysis of migration policy in the country was carried out by studying the legal framework for regulating migration processes in the country and various policy documents (concepts, strategies and state programs) that contain a description of measures and tools for influencing migration movement in the country and in its regions.

\section{Results}

Migration mobility of Kazakhstan population has been increasing its potential over the years of independence. In the early 1990s, migration flows in the post-Soviet space have increased due to the expansion of ethnic repatriation in all countries. Destruction of the "Soviet man" phenomenon in the minds of people, who, according to the established ideology, would feel at home anywhere he would be ("vast Homeland") throughout unified country, pushed them to realize their national identity and their attitude to the concept of "historic homeland". In addition, the collapse of the Soviet Union has led to the destruction of economic ties and the production crisis in the former Soviet republics. The decline in incomes, the crisis of payments, and the rapid devaluation of the ruble have led to increased economic factors of migration, and the population began to seek a "better life" and "where to survive better." Together, these reasons have led to an increase in 
the negative balance of migration to 406.7 thousand in 1994 (the outflow "peak"). By the early 2000s, the net outflow of population from Kazakhstan began to decline, and in 2004, the balance of external migration started showing positive values. A positive balance of migration would remain until 2011, that is, the flow of migrants entering the country would exceed the outflow. In 2012-2013, there was a slightly negative balance. Since 2014, the negative balance of external migration has been gradually increasing from 12,000 net outflows to 29,000 (Figure 1).

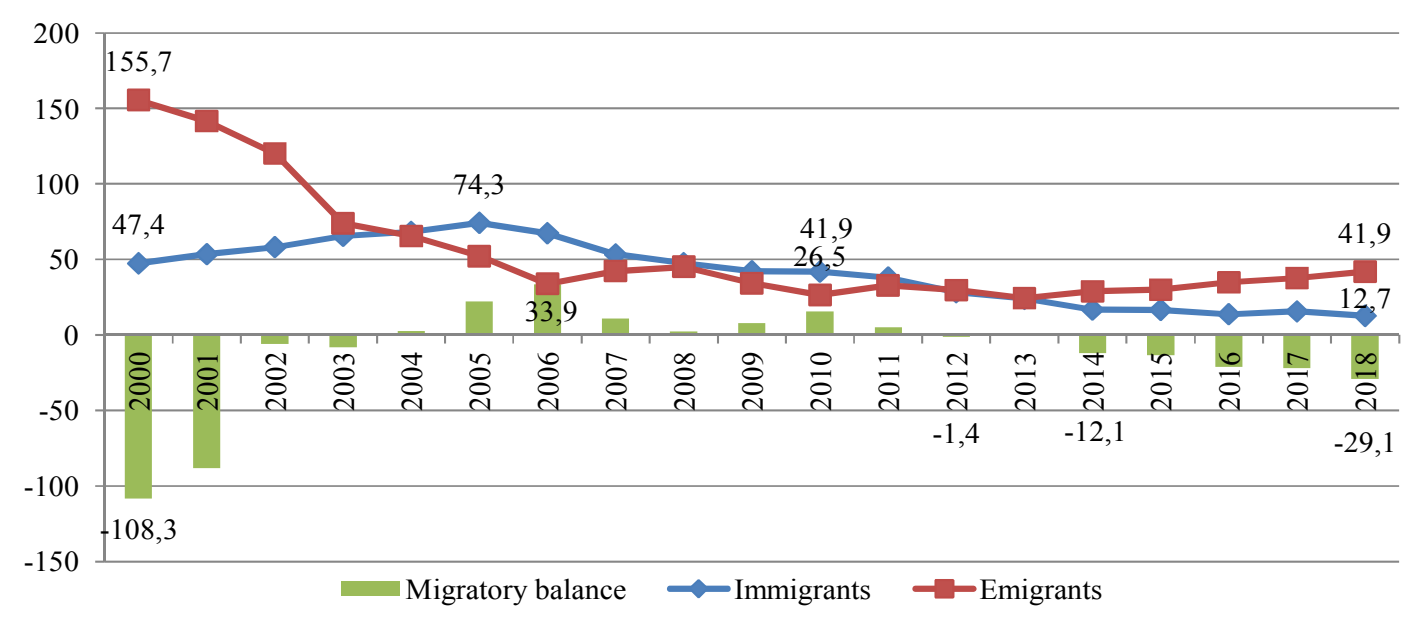

Figure 1. External migration trends in 2000-2018, thousands of people

Note: Compiled by the authors

The flow of foreign emigration would decrease significantly in the period of 2000-2006 from 155.7 thousand to 33 thousand people. Further, until 2013, the flow of emigrants from Kazakhstan would decrease to 24 thousand per year (with fluctuations up to 45 thousand in 2008). Until 2018, again, there was a gradual increase in the flow of emigration up to 43 thousand people.

The largest share of emigrants in the total flow of external emigration is accounted for by Russians as their share in the outgoing migrants was $70.6 \%$ in 2010 and $72.5 \%$ in 2019 . Germans and Ukrainians are next in terms of their share of outflows (Table 1). Most of them leave Kazakhstan for the Russian Federation (RF). This is most likely due to relatively higher wage levels and the pension size and benefits than in our country: about 1.5 times the cost of living and the minimum wage. Also attracting factors in the Russian Federation are measures supporting repatriation for emigrants from the CIS countries under the Compatriots state program.

Table 1. Ethnic structure of external migrants in 2019

\begin{tabular}{|l|r|r|r|r|r|}
\hline \multirow{2}{*}{ Total } & \multicolumn{2}{|c|}{ External Migration } & \multicolumn{3}{c|}{ In \% to total } \\
\cline { 2 - 6 } & Migratory balance & \multicolumn{1}{c|}{ Arrivals } & Departures & \multicolumn{1}{c|}{ Arrivals } & Departures \\
\hline Russians & $\mathbf{- 3 2 ~ 9 7 0}$ & $\mathbf{1 2} \mathbf{2 5 5}$ & $\mathbf{4 5 2 2 5}$ & & \\
\hline Kazakhs & -30128 & 2645 & 32773 & $21,6 \%$ & $72,5 \%$ \\
\hline Germans & 4860 & 7033 & 2173 & $57,4 \%$ & $4,8 \%$ \\
\hline Ukrainians & -2958 & 191 & 3149 & $1,6 \%$ & $7,0 \%$ \\
\hline Tatars & -2740 & 248 & 2988 & $2,0 \%$ & $6,6 \%$ \\
\hline Poles & -914 & 144 & 1058 & $1,2 \%$ & $2,3 \%$ \\
\hline Belarusians & -632 & 22 & 654 & $0,2 \%$ & $1,4 \%$ \\
\hline Uzbek & -508 & 49 & 557 & $0,4 \%$ & $1,2 \%$ \\
\hline Koreans & 44 & 286 & 242 & $2,3 \%$ & $0,5 \%$ \\
\hline Azerbaijanis & -76 & 162 & 238 & $1,3 \%$ & $0,5 \%$ \\
\hline Karakalpaks & 133 & 238 & 105 & $1,9 \%$ & $0,2 \%$ \\
\hline Note: Compiled by the authors & 285 & 301 & 16 & $2,5 \%$ & $0,0 \%$ \\
\hline
\end{tabular}


The flow of external immigration to Kazakhstan would grow from 47.4 in 2000 to 74.8 in 2005. Since 2006, there has been a constant decrease in the flow of external migrants to Kazakhstan to 42 thousand people by 2010 and to 12.7 thousand people by 2018. External immigration to Kazakhstan is closely linked to the ethnic repatriation of Kazakhs living in diaspores (irredentas) in the People's Republic of China, Mongolia, Uzbekistan, Turkmenistan, and Kyrgyzstan, as well as in the Russian Federation. From 1991 to January 1, 2020, 313,256 families or 1,057,280 ethnic Kazakhs have returned to their historical homeland and received the status of oralmans.

According to the Ministry of Labor and Social Protection of the Population, in 2019, 17,661 ethnic Kazakhs or 9,993 families have received status of oralmans. The majority of oralmans arrived from China: 41.5\% (7,326 people), Uzbekistan: 40.1\% (7,074 people), Turkmenistan: 6.5\% (1,152 people), Mongolia: $6.2 \%$ (1,095 people), Russia: $1.8 \%$ (313 people), and 3.9\% (701 people) from other countries.

The largest number of oralmans (38\%) have settled in Almaty region, 14\% in Mangistau region, $7 \%$ in Shymkent and 6\% in Nur-Sultan\%. Repatriates chose these regions for resettlement because of natural and climatic conditions similar to the countries of their origin (Almaty region, Shymkent), because of the desire to reunite with relatives who previously moved to these regions to facilitate the adaptation process, and because of better conditions for living, for employment, for teaching children in colleges and universities (Nur-Sultan).

Currently, measures to support repatriate resettlement to the Northern (Kostanay, North Kazakhstan, Akmola regions) and North-Eastern regions (Pavlodar and East Kazakhstan regions) are being implemented within the framework of the state program Enbek. According to the regional quota for accepting oralmans with a relocation compensation - a one-time payment of $35 \mathrm{MCI}$ to each family member (84.2 thousand tenge in 2019); from 15 to $30 \mathrm{MCI}$ (from 36.1 to 72.2 thousand tenge in 2019) per family to cover the costs of renting (tenancy) housing and paying monthly utility bills for 12 consecutive months. However, support covers only $11.5 \%$ of oralmans, and the majority of ethnic Kazakhs come regardless of whether they receive material support from the state, i.e. they have a different incentive for moving to their historic homeland (push factors in the country of origin, attracting factors in Kazakhstan).

To offset the negative balance of external migration in our country, we need to strengthen measures to encourage ethnic repatriation. Various NGOs dealing with the issues of adaptation of immigrants in Kazakhstan and support of foreign Kazakh diaspores propose the following measures: to expand the list of regions covered by the regional quota for receiving oralmans, to expand the list of benefits for potential repatriates, to increase the availability of support measures for them through activating measures to promote development of entrepreneurial initiatives of immigrants, their training and successful employment.

According to the well-known Kazakh expert A.N. Alekseyenko, "the main role of the repatriation of ethnic Kazakhs is to restore historical justice, eliminate disproportions of ethnodemographic development, and generally stabilize the demographic situation in Kazakhstan. But the more intensively immigration would develop, the more urgent issues of the "quality" of those arriving and their integration into the Kazakh society would become."

In 2019, of the working-age oralmans (who made up 62.7\% of all oralmans), $13.6 \%$ had higher education, $25.2 \%$ had specialized secondary education, $46.7 \%$ had general secondary education, and $14.5 \%$ had no education at all. In other words, there is a very high share of low-skilled labor among potential workers among the repatriates (more than half do not have a professional education). This leads to the fact that their adaptation is complicated by the complexity of their employment in regions with vacancies and a shortage of staff. Therefore, majority of repatriates seek to settle in rural areas to engage in animal husbandry (more often) or crop production (less often), and other forms of self-employment that do not require skilled labor (private transportation, small-scale trade, handymen). Such employment does not provide a stable income and makes it difficult for migrants to adapt to Kazakhstan's society. We need effective measures for professional retraining of repatriates in popular professions and improving their skills, developing useful skills for their self-development (business skills, computer literacy, language courses).

External migration in Kazakhstan has led to a change in the ethnic structure of the population:

- The number of European ethnic groups (Russians, Ukrainians, Poles, Belarusians) is decreasing due to intensive emigration and population aging processes, which leads to a decrease in their emigration potential in the future;

- Titular nation's share has increased from 53.2\% in 1999 to $63.1 \%$ in 2009 and then to $68 \%$ in 2019. This has been positively affected by both repatriation of ethnic Kazakhs and relatively high birth rate among Kazakhs. 
Factors for ethnic migration from Kazakhstan and to Kazakhstan are as follows:

- An active immigration policy in the countries where Kazakhstanis leave, which implies creation of preferential conditions for migrants ("lifting" allowances, benefits for purchasing housing, employment conditions, etc.). That is an attractive factor;

- Strengthening the position of Kazakh as the state language, increasing pressure on ethnic groups from representatives of the titular nation to study and use Kazakh everywhere (in documentation, education, the media, social networks, signage, etc.). That is a push factor for the Russian-speaking population;

- With the deterioration of socio-economic conditions, tensions in inter-ethnic relations increase, and manifestations of inter-ethnic discord increase in the southern regions of the country leading to local conflicts (climaxing in Kordai events in February 2020). That is a push factor;

- At the meso-level, small ethnic groups leave for their historic homeland to preserve their national identity (their language, culture, and traditions), in addition, they refrain from inter-ethnic marriages and maintain a connection with their historic homeland.

The above trends and factors of external migration present non-return migration of the population from/to Kazakhstan (for permanent residence). However, the scale of external migration processes in Kazakhstan is much broader and covers the flows of educational and labor migration.

Educational migration from Kazakhstan is growing dynamically. So according to UNESCO, in 2012, the number of students studying abroad was 42.5 thousand people. By 2016, this figure has increased to 90.2 thousand people, but in 2017, it decreased to 84.7 thousand students. According to UNESCO (Table 2), most Kazakhstan students go to study in Russia (about 65.2 thousand in 2017, or 77\%). There are flows of Kazakh students who chose Kyrgyzstan as their place of study (over 4 thousand people until 2016, and 3.3 thousand in 2017), the Czech Republic, the USA, the UK (in the range of 1000-2000 people each), followed by Germany, Malaysia, Poland, the United Arab Emirates, Canada, and France (300-750 people each).

The UNESCO database does not contain data on foreign students studying in educational institutions of the People's Republic of China (PRC). Therefore, the number of Kazakh citizens studying in China should be added to the UNESCO-specified flows of students from Kazakhstan.

Y. Sadovskaya's monograph offers the following figures: As part of the development of contacts between the two countries, an exchange of students began in the 2003-2004 academic year (20 students from universities in Kazakhstan). In 2006, about 1,200 Kazakh students were studying in China, 7874 people in 2010, 8287 people in in 2011 (according to the Chinese Embassy in Kazakhstan). Students would attend high schools both under state agreements on student exchange, and within the framework of the SCO University, and the Bolashak program (during the period of 2004 -2011, it helped 344 students get their education in China). In addition, a large influx of students came funded privately, at the expense of enterprises sending them for retraining and internships, and at the expense of their own families. First year of study in China is mostly devoted to learning Chinese. After the language courses, students take the HSK exam to certify their proficiency in Chinese and access further education in the Chinese higher education system.

Table 2. Kazakhstan students studying worldwide according to UNESCO

\begin{tabular}{|c|c|c|c|c|c|c|c|c|}
\hline \multirow{2}{*}{ Countries } & \multicolumn{6}{|c|}{ Kazakhstan students in the listed countries (people) } & \multicolumn{2}{|c|}{$\%$ of the total number } \\
\hline & 2013 & 2014 & 2015 & 2016 & 2017 & 2018 & 2016 & 2017 \\
\hline Russian Federation & & 49252 & 59295 & 69895 & 65237 & & $77,48 \%$ & $77,04 \%$ \\
\hline Kyrgyzstan & 4357 & 4535 & 4828 & 5318 & 4907 & 3290 & $5,90 \%$ & $5,79 \%$ \\
\hline Turkey & 10 & 1306 & 1799 & 1986 & 2015 & 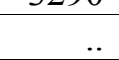 & $2,20 \%$ & $2,38 \%$ \\
\hline USA & 1884 & 1913 & 2006 & 1963 & 1707 & .. & $2,18 \%$ & $2,02 \%$ \\
\hline Great Britain & 1725 & 1596 & 1576 & 1545 & 1436 & .. & $1,71 \%$ & $1,70 \%$ \\
\hline Czech Republic & 1174 & 1376 & 1446 & 1515 & 1648 & & $1,68 \%$ & $1,95 \%$ \\
\hline Malaysia & & 1701 & 1443 & 1369 & 1002 & 808 & $1,52 \%$ & $1,18 \%$ \\
\hline Poland & 401 & 519 & 541 & 753 & 649 & .. & $0,83 \%$ & $0,77 \%$ \\
\hline Germany & 695 & 701 & 738 & 743 & 750 &.. & $0,82 \%$ & $0,89 \%$ \\
\hline South Korea & 211 & 251 & 375 & 546 & 659 & 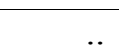 & $0,61 \%$ & $0,78 \%$ \\
\hline Canada & 357 & 429 & 444 & 480 & 483 & . & $0,53 \%$ & $0,57 \%$ \\
\hline UAE & 361 & 377 & 455 & 451 & .. & .. & $0,50 \%$ & \\
\hline France & 346 & 392 & 398 & 428 & 470 & .. & $0,47 \%$ & $0,56 \%$ \\
\hline
\end{tabular}


Back in January 2017, the Public Opinion Research Institute and the Confucius Institute at the L.N. Gumilyov ENU (Astana) jointly reported on the study of educational migration from Kazakhstan to China. The title of the work is "Educational Migration from the Republic of Kazakhstan to the People's Republic of China as One of the Aspects of Strategic Cooperation Between Countries." This paper examines in detail both quantitative and qualitative characteristics of the process of obtaining higher education by Kazakh students in China. The authors have interviewed more than 400 Kazakhstani students from 14 cities in China. Among the respondents, $64.6 \%$ were self-funded students, the share of students receiving China's educational grants was $32.7 \%$, and $2.7 \%$ received Kazakhstan grants.

Further, the report shows that for Kazakhstan today, China ranks second after Russia in the list of countries most popular for educational migration. Moreover, every year Chinese education is becoming more and more popular. If in 2007 there were about 3000 Kazakhstani students studying in China, as of February 2016, their number increased almost four times, amounting to 11,764 .

Educational migration from Kazakhstan may turn into a non-returnable form and there are risks of students studying abroad to staying permanently. This can also be facilitated by a higher pay level in the countries of study after graduation, the absence of barriers as some countries are ready to host talented and promising young people and offer them preferential conditions for obtaining permanent employment visas, a simplified citizenship procedure, and other advantages. The following factors can serve as factors of educational emigration of young people from Kazakhstan:

- Residents of the border regions of Kazakhstan go to Russia and Kyrgyzstan to enroll in universities and colleges in line with historical tradition (since the USSR), and due to the proximity (faster and easier travel than that with Kazakhstan educational centers) and a relative cheapness (tuition fees are comparable or cheaper than in Kazakhstan, travel, accommodation and food costs are relatively low or comparable in size to those in Kazakhstan). All the while, our countries being in the Eurasian Union facilitates the recognition of diplomas and certificates of partner countries on their territories (attracting factors);

- China has a policy of "soft power" for its neighbors, so it is relatively easy for Kazakh applicants to enter educational institutions in China. In addition, China allocates education grants to students from Kazakhstan (including representatives of the Dungan diaspore in Kazakhstan). That is an attractive factor;

- Introduction of trilingualism (Kazakh, Russian, English) in Kazakhstan (especially in schools for gifted children, and international schools) increases the potential of Kazakhstani applicants for admission to foreign universities;

- With the digitalization development, many people gain access to information on foreign education, rules of admission to foreign universities and colleges, intermediary companies helping to enter universities in Poland, the Czech Republic, Germany, Malaysia and other countries, study tours and training at preparatory courses and language courses in various countries;

- Development of the student academic mobility system, which also allows Kazakh students to study in other countries and consider the possibility of continuing their studies in other countries (e.g. getting a second education, or entering a Master's or Doctoral program). That is a push factor;

- Experience of the presidential program Bolashak showed Kazakh youth the opportunities of foreign education, the prestige of worldwide university graduation and the advantages of employment for worldwide graduates;

- A negative assessment of the quality of education in domestic educational institutions by some graduates of Kazakhstan's schools, colleges and universities. That is a push factor.

Educational migration flows to Kazakhstan are mostly related to the training of ethnic Kazakhs living abroad in educational institutions of our country in support of their subsequent repatriation and adaptation. Size of the admission quota for admission to study in educational institutions implementing educational programs of technical and professional, post-secondary and higher education for persons of Kazakh nationality who are not citizens of the Republic of Kazakhstan is set at 2 percent of the approved state educational order.

People migrate for labor from Kazakhstan mostly to the Russian Federation. According to the EAEC, in 2019, 136.2 thousand citizens of Kazakhstan entered Russia for labor, and over the past three years, the annual increase has been more than $20 \%$ per year (Figure 2). Over five years, the annual flow of migrants has increased almost 2 times (1.94 times). 


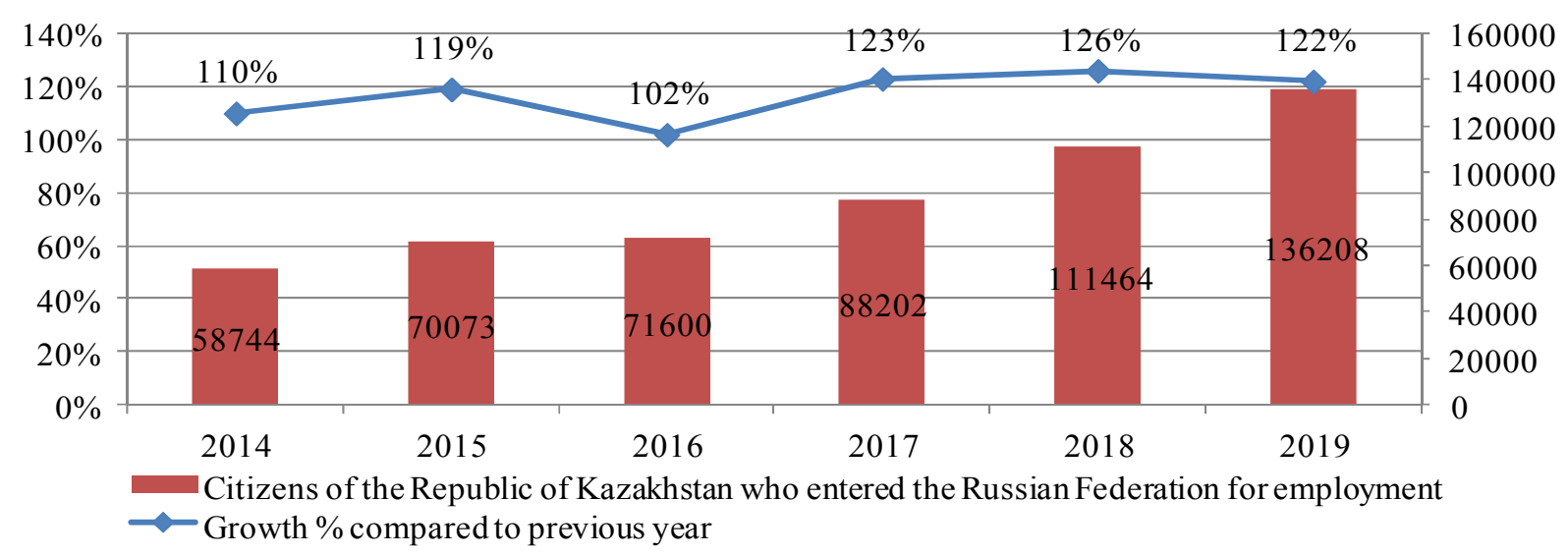

Figure 2: Labor migration from Kazakhstan to Russia in 2014-2019

Note: Compiled by the authors

Trends of money transfers from Russia to Kazakhstan in 2015-2019 (Figure 3) shows that in 2017, money transfers have increased sharply by more than three times, and this may be due to the increase in the number of labor migrants from Kazakhstan to Russia. From 2017 to 2019, money transfers decreased, but this may be due to the fact that in these years, online card to card transfers (i.e. not through a money transfer system) were developing, which do not record country to country transfers. For example, online transfers between Kaspi Gold cardholders.

Citizens of the Republic of Kazakhstan who entered the Russian Federation for employment

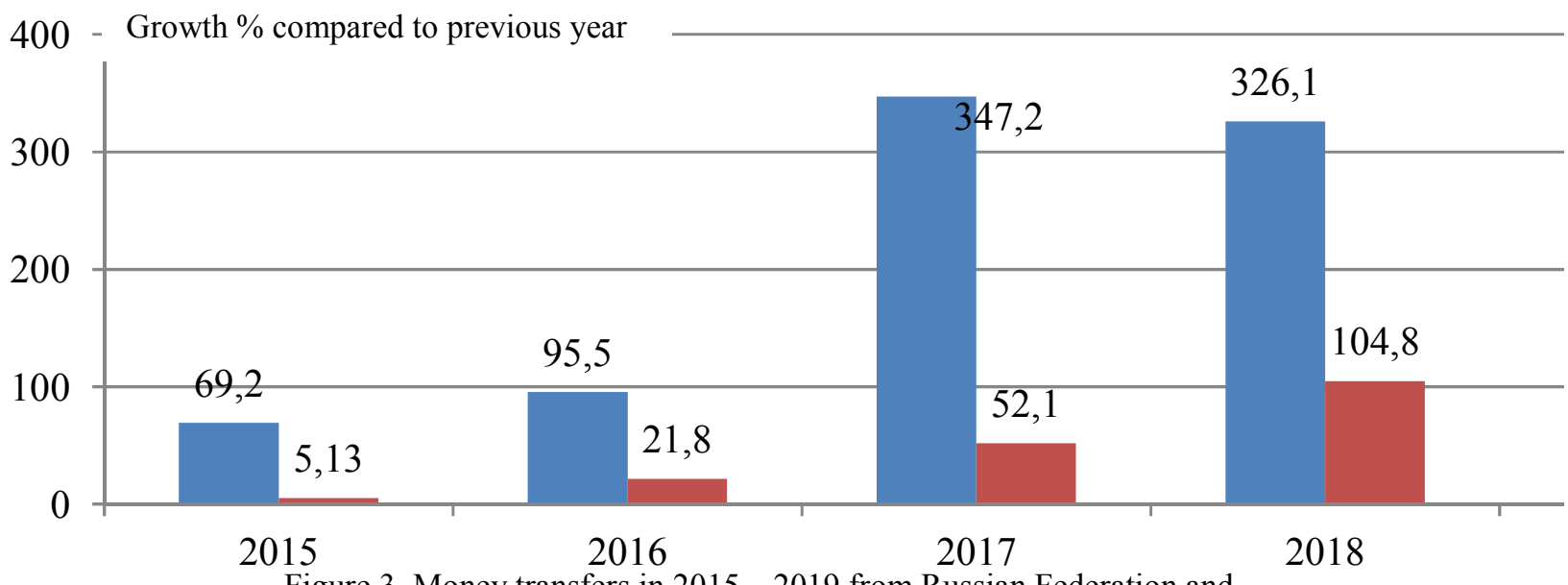

Figure 3. Money transfers in 2015-2019 from Russian Federation and

Note: Compiled by the authors

South Korea to Kazakhstan (million USD)

Labor emigration from Kazakhstan has also been active in recent years to the Republic of Korea (South Korea), so if in 2015 money transfers from this country amounted to 5.13 million USD, by 2019 they have grown to 112.8 million USD. Transfers from these two countries accounted for $63-72 \%$ of the total amount of personal transfers from worldwide to Kazakhstan in the last three years. Moreover, some of the Kazakh migrant workers in South Korea would work illegally. For example, at the beginning of 2019, there were 12 thousand illegal workers from Kazakhstan in this country, then the authorities decided to provide them with a "green corridor," an opportunity to leave the country no penalties applied, and by the fall of 2019, their number was reduced to 9 thousand people.

Unregulated flows of labor migration to European countries exist as well. For example, at the end of September 2019, 59 semi-legal Kazakhstan migrants who had entered the country for seasonal work were identified in Norway and were deported back. 
The main factors of labor migration from Kazakhstan include a significant difference in wage levels in Kazakhstan and in the countries where labor migrants go, and a "push factor:" difficulties finding a permanent and well-paid job in the region of exodus.

Labor immigration to Kazakhstan from other countries can also be divided into regulated (legal) and unregulated ones. The first one includes the following flows: 1) foreign workforce (FW) with LEA permits; 2) migrants working for individuals under migration police permits; 3) foreign workers who independently obtain work permits in the Republic of Kazakhstan based on certificates for the list of popular professions in the Republic of Kazakhstan; and 4) citizens of the EAEU countries who freely move around the participating countries and have the right to seek employment without permits.

Unregulated migration is represented by the following: 1) foreigners who have entered Kazakhstan legally, but engaged in informal employment and business activity in the RK; and 2) foreign citizens illegally staying in the RK who are also illegally employed or engaged in entrepreneurial activities without official registration and proper legal protection.

Kazakhstan registers labor migrants mainly just by the flow of foreign workforce (FW) attracted by enterprises with the permission of local executive authorities. For example, according to the database of the Ministry of Labor and Social Protection of the Population, the peak of labor migration under LEA permits occurred in 2007 and 2008, when 58.8 and 54.2 thousand foreign citizens would work under such permits, respectively.

Then, until 2012, the number of foreign employees attracted with LEA permits would reduce to 24 thousand people. Then, until 2015-2016, their number would once again increase to 36-38 thousand people. In 2017, 27.7 thousand permits were issued. As of April 1 ${ }^{\text {st }}, 2020,19,952$ foreign citizens were working in Kazakhstan under LEA permits to attract WF.

According to Y. Sadovskaya, "In the mid-2000s, more than a million people would come to Kazakhstan as labor migrants annually, which, according to estimates, accounted for 10 to 12 percent of the country's gross domestic product (GDP)." Here, the expert's assessment also includes the volume of unregulated labor migration that is not recorded in the state body and LEA databases.

In 2016, the Commission on Human Rights under the President of the Republic of Kazakhstan issued the Bulletin "Migrant Workers in Kazakhstan: No Status, No Rights," which indicates that the situation of Uzbekistan and Tajikistan workers in Kazakhstan is particularly vulnerable since the vast majority of them do not have their status regulated. Often, they do not have the right to work or a residence permit. As temporary migrants, they depend on their job and employer, while having limited access to social services provided to permanent residents. Working on construction sites lacking safety precautions, and as domestic workers, who are particularly vulnerable to abuse due to their isolated state, they often become victims of exploitation, forced labor or human trafficking. The situation is easier for migrants from Kyrgyzstan who can freely work in the Republic of Kazakhstan. According to EAEC estimates, 5.5 thousand Kyrgyzstanis would work in Kazakhstan in 2018, and 5.8 thousand in 2019.

Factors of labor migration from the country (push factors) are as follows:

- Higher wages in countries accepting migrant workers (in the Russian Federation and South Korea). For example, even the minimum wage in the Russian Federation is more than 1.5 times higher than in Kazakhstan ( $\$ 157$ versus $\$ 98$ at the current exchange rate);

- Jobs deficit in labor-surplus regions (southern, south-eastern and western regions) and in some depressed territories (rural areas and single-industry towns).

If the intensity of external migration has generally decreased in recent years, internal migration of the population has become more active. If in the early 2000s the flow of internal migration was at the level of 300 thousand people per year, by 2017-2018, these flows have grown to 900 thousand people per year (Figure 4). According to statistics, a sharp increase in internal migration has occurred in these years due to the strengthening of measures for temporary registration of citizens in 2016-2017, which allowed the increase in the number of citizens registered at the place of residence. Control over the registration of citizens (legalization) has been strengthened. On December $22^{\text {nd }}, 2016$, the Law "On amendments and supplements to certain legislative acts of the Republic of Kazakhstan on countering extremism and terrorism" came into force. One of the norms this document has introduced was mandatory registration of Kazakhstan citizens at the place of their temporary stay. Sanctions have been introduced not only for citizens who do not live at the place of registration or do not have one, but also for owners of housing where unregistered citizens live. At the same time, procedures for registering citizens have been simplified. During the legalization campaign in 2016, 1 million 422 thousand citizens registered, and after the introduction of the law with stricter measures 
in only 9 months of 2017, 2 million 461 thousand people registered, of which 988 thousand were temporarily registered.

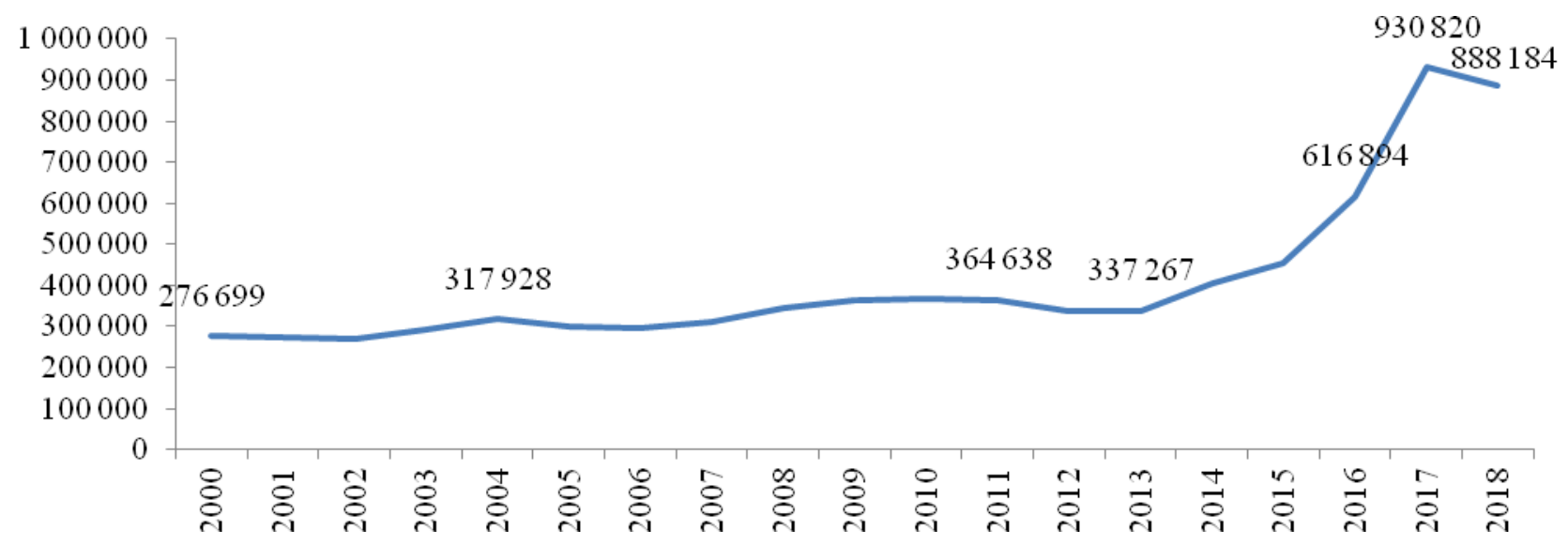

Figure 4. Internal migration flows in Kazakhstan in 2000 - 2018, people

Note: Compiled by the authors

In other words, these measures have made it possible to bring unregistered internal migrants out of the shadows, but in reality, many of them came earlier and have been living for some time unregistered. Accordingly, the number of internal migrants was previously underestimated, and after the measures taken to register the number of migrants increased not only due to the real growth of internal migrant flows over the current period, but also due to the legalization of the status of previously arrived persons. But in general, according to statistical indicators, internal migration has gained momentum in recent years and in 2018, 888 thousand citizens were registered in its flows, which is about three times more than at the beginning of the period under review.

In general, the growth of internal migration flows is associated with the development of urbanization (relocation of rural residents to cities), and the transfer of the capital from Almaty to Astana (Nur-Sultan), the intensive development of cities of national significance, and the growth of their attractiveness for internal migrants also played an important role. They have relatively high pay, better conditions for employment and entrepreneurial initiatives, and good quality of life indicators due to developed infrastructure, which makes these cities a center of attraction for internal migration. Moreover, internal migration is of a step-by-step nature. Flows from regions, especially from large cities, to cities of national significance, from small cities to large cities, and from villages to cities (educational and labor migration with subsequent transformation into non-returnable migration).

"The main reason for the transfer of the capital is the desire to achieve a regional ethno-demographic balance, encourage migration from labor-surplus southern regions to industrially developed cities in the north, and involve Kazakh population in industrial and agricultural production in Central and Northern Kazakhstan," says migration expert Yelena Sadovskaya.

Factors that attract people to cities from villages, from small towns to larger cities are as follows: pay level difference, a higher living standard (more comfortable housing conditions, leisure activities, developed infrastructure and communications), better education conditions (colleges, universities, equipment with educational materials), a higher level of education in urban schools (staffing of subject teachers, in-depth study of subjects, availability of schools for gifted children, etc.). It is also an important factor that cities have better conditions for employment than rural areas (where self-employment and the informal sector are more common). Demographic factors also play an important role in interregional migration. Thus, the main donors of internal migrants are regions with a rapidly growing population, mainly with agricultural specialization. Labor markets in such regions cannot "absorb" the excess supply of labor. Accordingly, some people who cannot find jobs in such labor-surplus regions tend to go to large cities where there is an unsatisfied demand for labor in service and industrial production sectors. In addition, young people from such regions tend to go to study in large cities to increase their competitiveness and in the future get a "good" job (with a permanent, stable income and social security, in the formal sector of the economy).

\section{Discussions}


This is an overview paper presenting the trends of migration processes in modern Kazakhstan based on statistical data mainly focusing on the analysis of external migration flows, including flows of permanent migration (permanent residence in another country), educational and labor migration. We have also discussed the issues of internal migration in Kazakhstan. For external migration, we have emphasized high importance of an ethnic component of the determinants of migration activity: of those leaving Kazakhstan mostly are representatives of European ethnic groups, while arriving are ethnic repatriates, Kazakhs from neighboring countries (Uzbekistan, China, Mongolia, and the Russian Federation).

The paper also presents the factors both pulling people in Kazakhstan (and other countries) and pushing them out of Kazakhstan (and other countries). These are economic factors, such as differences in income levels, quality of life, employment conditions, and the state of labor markets. Demographic factors play an important role, e.g. the aging of the population in some countries/regions leads to an active policy of attracting migrants from other countries. On the contrary, high natural growth in some countries leads to excessive pressure on labor markets, resources, and social infrastructure, and "pushes" migrants out of the countries/regions of origin. These factors are more associated with the macro-level as at the micro level, a greater role for spatial mobility are both individual preferences and expectations of potential migrants, their tendency to change places and adaptability to environmental changes and family values, and the capacity of families to support the decisions of migration of its members (material and moral support), the readiness of the family to hardship and cost of moving and adapting in a new place. The migration policy pursued by the state in regulating foreign immigration in Kazakhstan (the policy of supporting ethnic repatriation and working with ethnic Kazakh diaspores abroad) and in internal migration (the quota of internal migration and resettlement under "Enbek" - the state program for supporting productive employment and mass entrepreneurship) is also of some importance. Indirect influence is provided by regional development policies (in terms of equalizing regional differences, in terms of planning population settlement), infrastructure development, policies to support SMEs, and sectoral development. Language, inter-ethnic relations measures within the country, and measures to stabilize the socio-economic situation in the country play an important role in regulating emigration activity. The policy of regulating migration in the countries emigrants leave for is also important, that is, how much does it favor migrants from Kazakhstan: how much have barriers to entry and adaptation of migrants in the country been removed? What conditions have been created for living, employment, educational and medical services? What environment is created for the successful integration of migrants in the host society?

\section{Conclusions}

The peak of external migration activity was passed at the turn of the late 1990s-early 2000s, then until 2012 it would decrease. In recent years, since 2013, the negative balance of external migration has been growing back again, which indicates a steady excess of the number of people leaving Kazakhstan over those arriving. External non-return migration from/to Kazakhstan is ethnically expressed as follows: the leaving is mostly population of European ethnic groups, while ethnic Kazakhs mostly arrive. In recent years, educational and labor migration from Kazakhstan to other countries has become more active. The geography of countries where applicants from Kazakhstan go to study is expanding. Labor immigration is dominated by the flow to the Russian Federation, which is primarily due to relatively favorable adaptation conditions (there is no language barrier, similar production conditions and forms of labor organization, a relatively supportive population - a common USSR history). Also, recently, labor migration from Kazakhstan has been actively moving to South Korea.

In recent years, the following push/pull factors have been active:

1) Social factors: The desire to return to their historic homeland, reunite with their families, get away from the manifestations of everyday nationalism, and the language situation (increasing the scope of the state language);

2) Economic factors: different conditions of employment and support for entrepreneurship; the difference in the pay levels and social benefits, pensions in Kazakhstan and in the countries where emigrants leave for (mainly Russia, Germany, USA), and where immigrants come from (Uzbekistan, Kyrgyzstan);

3) Political factors: The difference in the population mentality, the perception of freedom of speech, policy in the inter-ethnic sphere and in the policy regarding national minorities (China), and language policy; 
4) Demographic factors: threats of depopulation and active processes of population aging in some countries/regions (recipients of migration), on the other hand, rapid population growth due to the relatively high birth rate and low mortality rate in other countries/regions (migration donors).

Currently, quarantine measures can make their own adjustments to the migration activity of citizens of Kazakhstan in the context of the coronavirus pandemic, since entry/exit to and from countries is restricted to avoid the spread of the virus. This greatly restricts the flow of tourists between countries, reduces external migration flows, changes the plans of potential migrants, and makes adjustments to the migration timing, routes, and estimates of the material and non-material costs.

\section{References}

Alekseyenko, A.N. (2008). Rol immihratsii v formirovanii demohraficheskoi politiki Respubliki Kazakhstan [The Role of Immigration in Shaping the Demographic Policy of the Republic of Kazakhstan]. Demoskop weekly Elektronnaia versiia biulletenia «Naselenie i obshchestvo» - Institut demohrafii Hosudarstvennoho universiteta - Vysshei shkoly ekonomiki, 355-356. Retrieved from URL: http://www.demoscope.ru/weekly/2008/0355/analit04.php [in Russian]..

Bondyreva, S.K., \& Kolesov, D.V. (2017). Mihratsia: sushchnost i yavlenie [Migration (essence and the phenomenon)]. Moscow: Moscow psychological and social Institute [in Russian].

Castles, S., Miller, M. (1993). The age of migration: international population movements in the modern world. London: Macmilla.

Doklad Mezhdunarodnoi orhanizatsii po mihratsii (MOM), Ahentstva OON po mihratsii (2017). Vozvratnaia mihratsiia i vyzovy v Tsentralnoi Azii: analiz riskov [Risk Analysis on Return Migration and Challenges in Central Asia]. Retrieved from URL: https://pdfslide.tips/documents/-iomkz-.html [in Russian]..

Fasani, F., Llull, J., Tealdi, C. (2020). The economics of migration: Labour market impacts and migration policies (Editorial). Labour Economics, 67, Article number 101929. Retrieved from URL: https://www.scopus.com/record/display. uri?eid=2-s2.0-85092009324\&origin=resultslist\&sort=plf$\mathrm{f} \& \mathrm{src}=\mathrm{s} \& \mathrm{sid}=5303 \mathrm{f} 2 \mathrm{ee} 9 \mathrm{~d} 8 \mathrm{f} 55003 \mathrm{c} 7 \mathrm{f} 45 \mathrm{e} 3 \mathrm{a} 615 \mathrm{bc} 1 \mathrm{~b} \& \mathrm{~s} \quad \mathrm{ot}=\mathrm{a} \& \mathrm{sdt}=\mathrm{a} \& \mathrm{sl}=30 \& \mathrm{~s}=\mathrm{TITLE}-\mathrm{ABS}-$ KEY\%28labor+migration\%29\&relpos=18\&citeCnt=0\&searchTerm=\# $\quad$ references. 10.1016/j.labeco.2020.101929

Harris, J., Todaro, M. (1970). Migration, Unemployment, and Development: A Two-Sector Analysis. The American Economic Review, 60, 126-142.

Kaukenova, T. (2017). Ucheba v Kitae: cheho hotiat i chto poluchaiut nashi studenty [Studying in China: what our students want and get]. Retrieved from URL: https://www.zakon.kz/4846930-ucheba-v-kitae-chego-khotjat-i-chto.html [in Russian]..

Mamyrhanova, M. (2019). Trudovykh mihrantov iz Kazakhstana deportirovali iz Norvehii [Labor migrants from Kazakhstan were deported from Norway]. Retrieved from URL: https://kursiv.kz/news/obschestvo/2019-09/trudovykhmigrantov-iz-kazakhstana-deportirovali-iz-norvegii [in Russian]..

Otchet Mezhdunarodnoi federatsii po pravam cheloveka (FIDH) (2016). Trudovye mihranty v Kazakhstane: bez statusa i prav [Labor migrants in Kazakhstan: without status and rights]. Retrieved from URL: https://www.fidh.org/IMG/pdf/note_kazakhstan_681r_6_sept_2016_ru_web.pdf [in Russian]..

Ofitsialnyi sait Evraziiskoi ekonomicheskoi komissii [Official website of the Eurasian economic Commission]. Retrieved from URL: http://www.eurasiancommission.org/ru/act/finpol/migration/Pages/statistical_data.aspx [in Russian]..

Ofitsialnyi sait YuNESKO [Official website of UNESCO]. Retrieved from URL: http://uis.unesco.org/indicator/edumobility-in-country [in Russian]..

Pospelov, V.K. (2017). Mirovaia ekonomika i mezhdunarodnye ekonomicheskie otnoshenia [World economy and international economic relations]. Moscow: INFRA-M [in Russian]..

Rukovodstvo po identifikatsii i perenapravleniiu mihrantov i chlenov ikh semei v uiazvimykh situatsiiakh [Guidelines for the Identification and Referral of Migrants and Their Family Members in Vulnerable Situations]. (2018). Mezhdunarodnaia orhanizatsiia po mihratsii (MOM), Ahentstvo OON po mihratsii. Retrieved from URL: https://kazakhstan.iom.int/sites/kazakhstan/files/documents/Guidelines\%20for\%20the\%20identification\%20and\%20 referral_FINAL_IOM_RUS\%201.pdf [in Russian]..

Sadovskaja, Y.Y. (2014). Kitaiskaia mihratsiia v Respubliku Kazakhstan: traditsii Shelkovoho puti i novye vektory sotrudnichestva [Chinese Migration to the Republic of Kazakhstan: Silk Road Traditions and New Cooperation Vectors]. Almaty: Raritet [in Russian]..

Sadovskaja, Y.Y. (2009). Kitaiskie mihranty v Kazakhstane: otnoshenie kazakhstanskikh hrazhdan (po rezultatam sotsiolohicheskoho issledovaniia) [Chinese migrants in Kazakhstan: The attitude of Kazakhstan citizens (based on the results of a sociological study)]. Demoskop weekly Elektronnaia versiia biulletenia "Naselenie i obshchestvo». Institut demohrafii Hosudarstvennoho universiteta - Vysshei shkoly ekonomiki, 367-369. Retrieved from URL: http://demoscope.ru/weekly/2009/0367/analit04.php [in Russian].

Sadovskaja, Y.Y. (2002). Perenos stolitsy iz Alma-Aty v Astanu i eho vliianie na mihratsionnye protsessy v Kazakhstane [Transfer of the Capital from Alma-Ata to Astana and its Impact on Migration Processes in Kazakh- 
stan]. Demoskop weekly Elektronnaia versiia biulletenia Naselenie $i$ obshchestvo - Institut demohrafii Hosudarstvennoho universiteta - Vysshei shkoly ekonomiki, 71-72. Retrieved from URL: http://www.demoscope.ru/weekly/2002/071/analit03.php [in Russian]..

Sadovskaja, Y.Y. (2002). Repatriatsiia etnicheskikh kazakhov v Kazakhstan [Repatriation of ethnic Kazakhs to Kazakhstan]. Demoskop weekly Elektronnaia versiia biulletenia "Naselenie i obshchestvo» - Institut demohrafii Hosudarstvennoho universiteta - Vysshei shkoly ekonomiki, 69-70. Retrieved from URL: http://www.demoscope.ru/weekly/2002/069/analit05.php [in Russian].

Sadovskaja, Y.Y. (2016). Trudovaia mihratsiia v Tsentralnoi Azii [Labour Migration in Central Asia]. Ofitsialnyi sait Orhanizatsii po bezopasnosti i sotrudnichestvu v Evrope [Official website of the Organization for Security and Cooperation in Europe]. Retrieved from URL: http://www.demoscope.ru/weekly/2002/069/analit05.php [in Russian].

Sassen, S. (1988). The Mobility of Labor and Capital: A Study in International Investment and Labor Flow. New York: Cambridge University Press

Skolko oralmanov pribyli v Kazakhstan [How many oralmans arrived in Kazakhstan] (2020). Ministerstvo truda $\mathrm{i}$ sotsialnoi zashchity naselenia. Retrieved from URL: https://zakon-kz.turbopages.org/s/zakon.kz/5003829-skolkooralmanov-pribyli-v-kazahstan.html [in Russian].

Syzdykbekov, E.S., Rahmetova, A.M., \& Grazhevskaja, N.I. (2019). Rehulirovanie vneshnei trudovoi mihratsii v Respublike Kazakhstan: problemy i vozmozhnosti [Regulation of external labor migration in the Republic of Kazakhstan: problems and opportunities]. Vestnik Karahandinskoho universiteta. Seriia Ekonomika, 93-1, 208-214 [in Russian].

Vasilenko, P.V. (2013). Zarubezhnye teorii mihratsii naseleniia [Foreign Theories of Population Migration]. Pskovskii rehionolohicheskii zhurnal, 16, 36-42 [in Russian].

Vremennaia rehistratsiia vyvela v 2017 hodu iz «teni» okolo milliona kazakhstantsev [In 2017, temporary registration has brought about one million Kazakhstanis out of the shadows] (2017). Mezhdunarodnoe informatsionnoe ahentstvo Kazinform. Retrieved from URL: https://www.inform.kz/ru/vremennaya-registraciya-vyvela-v-2017godu-iz-teni-okolo-1-mln-kazahstancev_a3068388 [in Russian].

\section{С.Т. Мусина, Ж.С. Хусаинова, Е.А. Вечкинзова}

\section{Қазақстандағы көші-қон процестері: үрдістер, ерекшеліктер, факторлар}

\section{Аңдатпа}

Maқ̧саты: Қазақстандағы сыртқы және ішкі көші-қонның негізгі үрдістерін анықтау, оның әртүрлі ағындарына тән ерекшеліктерді зерттеу, сондай-ақ көші-қон процестеріне әсер ететін экономикалық және демографиялық факторларды сипаттау. Қазақстан Республикасындағы көші-қон процестері.

Әдісі: Жүйелік, динамикалық және құрылымдық талдау, себеп-салдарлық байланыстарды зерттеу әдістері.

Қорытынды: Соңғы онжылдықтардағы Қазақстандағы сыртқы және ішкі көші-қон серпініндегі үрдістер анықталды; Қазақстандағы көші-қон ағындарының сипатты белгілері зерттелді және халықтың көші-қон белсенділігіне әсер ететін факторлар зерттелді; Қазақстандағы реттелмейтін көші-қон проблемасы қаралды және онымен байланысты тәуекелдер, сондай-ақ осы проблеманы шешудегі көші-қон саясатының мүмкіндіктері сипатталды.

Тұжырымдама: Кейінгі жылдары сыртқы көші-қонның теріс сальдосы өсуде - Қазақстаннан таза ағым жүріп жатыр. Бұрын эмиграция ағынын жапқан қазақтардың этникалық репатриациясының қарқындылығы төмендеуде. Қазақстаннан көшіп-қонушылардың кетуін тежеу және Қазақстанға көшіп келуді ынталандыру жөнінде шаралар қажет. Соңғы жылдары көші-қон саясаты ішкі көші-қон саласында белсенді жүргізілді: көшіпқонушыларды ел ішінде тіркеу тетігі күшейтілді, Қазақстанның солтүстік және солтүстік-шығыс өңірлеріне қоныс аудару бойынша квота жұмыс істеуде.

Kiлm сөздер: Көші-қон, сыртқы көші-қон, ішкі көші-қон, реттелмейтін көші-қон, көші-қон қарқындылығы, көші-қонның экономикалық факторлары, көші-қон саясаты.

\section{С.Т. Мусина, Ж.С. Хусаинова, Е.А. Вечкинзова}

\section{Миграционные процессы в Казахстане: тенденции, специфика, факторы}

\section{Аннотация}

Цель: Выявить основные тенденции во внешней и внутренней миграции в Казахстане, изучить характерные для ее разных потоков особенности, а также описать экономические и демографические факторы, влияющие на миграционные процессы в Республике Казахстан.

Memoдbl: Методы системного, динамического и структурного анализа, изучения причинно-следственных связей.

Pезультаты: Выявлены тенденции в динамике внешней и внутренней миграции в Казахстане в последние десятилетия; исследованы характерные черты миграционных потоков в Казахстане и изучены факторы, влияющие на миграционную активность населения; рассмотрена проблема нерегулируемой миграции в Казах- 
стане и описаны риски, связанные с ней, а также возможности миграционной политики в решении этой проблемы.

Bblвoдbl: В последние годы нарастает отрицательное сальдо внешней миграции - идет чистый отток из Казахстана. Снижается интенсивность этнической репатриации казахов, которая ранее закрывала поток эмиграции. Необходимы меры по сдерживанию оттока мигрантов из Казахстана и по стимулированию иммиграции в Казахстан. В последние годы миграционная политика активно велась в сфере внутренней миграции: усилен механизм регистрации мигрантов внутри страны, действует квота по переселению в северные и северовосточные регионы Казахстана.

Ключевые слова: миграция, внешняя миграция, внутренняя миграция, нерегулируемая миграция, интенсивность миграции, экономические факторы миграции, миграционная политика.

\section{References}

Castles S., Miller M. (1993). The age of migration: international population movements in the modern world. — London: Macmilla. - 306 p.

Fasani F., Llull J., Tealdi C. The economics of migration: Labour market impacts and migration policies (Editorial) // Labour Economics. - Volume 67. - December 2020. — Номер статьи 101929 (https://www.scopus.com/record/display.uri? $\quad$ eid=2-s2.0-85092009324\&origin=resultslist\&sort=plf$\mathrm{f} \& \mathrm{src}=\mathrm{s} \& \mathrm{sid}=5303 \mathrm{f} 2 \mathrm{ee} 9 \mathrm{~d} 8 \mathrm{f} 55003 \mathrm{c} 7 \mathrm{f} 45 \mathrm{e} 3 \mathrm{a} 615 \mathrm{bc} 1 \mathrm{~b} \& \mathrm{sot}=\mathrm{a} \& \mathrm{sdt}=\mathrm{a} \& \mathrm{sl}=30 \& \mathrm{~s}=\mathrm{TITLE}-\mathrm{ABS}-$

KEY\%28labor+migration\%29\&relpos=18\&citeCnt=0\&searchTerm=\#references).

doi: 10.1016/j.labeco.2020.101929.

Harris J., Todaro M. Migration, Unemployment, and Development: A Two-Sector Analysis // The American Economic Review. - 1970. — № 60. — P.126-142.

Sassen S. The Mobility of Labor and Capital: A Study in International Investment and Labor Flow. / New York: Cambridge University Press, 1988. - P. 240.

Алексеенко А.Н. Роль иммиграции в формировании демографической политики Республики Казахстан / А.Н. Алексеенко // Демоскоп weekly Электронная версия бюллетеня «Население и общество» - Институт демографии Государственного университета — Высшей школы экономики. - 1-14 декабря 2008 г. № 355-356. — (http://www.demoscope.ru/weekly/2008/0355/analit04.php).

Василенко П.В. Зарубежные теории миграции населения / П.В. Василенко // Псков. регион. журн. — 2013. № 16. - С. 36-42.

Возвратная миграция и вызовы в Центральной Азии: анализ рисков 2017. — Международная организация по миграции (МОМ), Агентство ООН по миграции, 2017. — (https://pdfslide.tips/documents/-iomkz-.html).

Временная регистрация вывела в 2017 году из «тени» около 1 млн казахстанцев // Международное информационное агентство Kazinform. - 25 сентября 2017 г. - (https://www.inform.kz/ru/vremennaya-registraciyavyvela-v-2017-godu-iz-teni-okolo-1-mln-kazahstancev_a3068388).

Миграция: сущность и явление: учеб.-метод. пос. / С.К. Бондырева, Д.В. Колесов. - М.: Изд-во Моск. психол.соц. ин-та, 2017. — 294 с.

Мировая экономика и международные экономические отношения [Текст]: учеб. / под ред. В.К. Поспелова. М.: ИНФРА-М, 2017. - 369 с.

Отчет Международной федерации по правам человека (FIDH) «Трудовые мигранты в Казахстане: без статуса и прав». — Сентябрь 2016. — № 681. — (https://www.fidh.org/IMG/pdf/note_kazakhstan_681r_6_sept_2016_ru_ web.pdf).

Официальный сайт Евразийской экономической комиссии. - (http://www.eurasiancommission.org/ru/act/finpol /migration/Pages/statistical_data.aspx).

Официальный сайт ЮНЕСКО̄. — (http://uis.unesco.org/indicator/edu-mobility-in-country).

Руководство по идентификации и перенаправлению мигрантов и членов их семей в уязвимых ситуациях. //Международная организация по миграции (МОМ). Агентство ООН по миграции. - 2018. (https://kazakhstan.iom.int/sites/kazakhstan/files/documents/Guidelines\%20for\%20the\%20identification\%20and\%2 Oreferral_FINAL_IOM_RUS\%201.pdf)

Садовская Е.Ю. Китайская миграция в Республику Казахстан: традиции Шелкового пути и новые векторы сотрудничества / Е.Ю. Садовская. - Алматы: Раритет, 2014. - 444 с.

Садовская Е. Китайские мигранты в Казахстане: отношение казахстанских граждан (по результатам социологического исследования) / Е. Садовская // Демоскоп weekly Электронная версия бюллетеня «Население и общество» - Институт демографии Государственного университета - Высшей школы экономики. - 2-16 марта 2009. — № 367-369. — (http://demoscope.ru/weekly/2009/0367/analit04.php).

Садовская Е. Перенос столицы из Алма-Аты в Астану и его влияние на миграционные процессы в Казахстане / Е. Садовская // Демоскоп weekly Электронная версия бюллетеня «Население и общество» - Институт демографии Государственного университета — Высшей школы экономики. — 17-30 июня 2002. — № 71, 72. — (http://www.demoscope.ru/weekly/2002/071/analit03.php). 
Садовская Е. Репатриация этнических казахов в Казахстан / Е. Садовская // Демоскоп weekly Электронная версия бюллетеня «Население и общество» - Институт демографии Государственного университета - Высшей школы экономики. — 3-16 июня 2002 г. — № 69-70. — (http://www.demoscope.ru/weekly/2002/069 /analit05.php).

Садовская Е. Трудовая миграция в Центральной Азии / Е. Садовская // Официальный сайт Организации по безопасности и сотрудничеству в Европе. — 4 июля 2016 г. — (https://www.osce.org/ru/magazine/250406).

Сколько оралманов прибыли в Казахстан // Министерство труда и социальной защиты населения. — 22 января 2020 г. - (https://zakon-kz.turbopages.org/s/zakon.kz/5003829-skolko-oralmanov-pribyli-v-kazahstan.html).

Сыздыкбеков Е.С. Регулирование внешней трудовой миграции в Республике Казахстан: проблемы и возможности / Е.С. Сыздыкбеков, А.М. Рахметова, Н.И. Гражевская // Вестн. Караганд. ун-та. Сер. Экономика. 2019. — № 1 (93). — С. 208-214.

Мамырханова М. Трудовых мигрантов из Казахстана депортировали из Норвегии / М. Мамырханова. 30.09.2019 г.. — (https://kursiv.kz/news/obschestvo/2019-09/trudovykh-migrantov-iz-kazakhstana-deportirovaliiz-norvegii).

Каукенова Т. Учеба в Китае: чего хотят и что получают наши студенты / Т. Каукенова. - 2 марта 2017 г. (https://www.zakon.kz/4846930-ucheba-v-kitae-chego-khotjat-i-chto.html). 